\title{
Wind power potential assessment for seven buoys data collection stations in Aegean Sea using Weibull distribution function
}

\author{
Haralambos S. Bagiorgas, ${ }^{1, a)}$ Giouli Mihalakakou, ${ }^{1, b)}$ Shafiqur Rehman, ${ }^{2,3, c)}$ \\ and Luai M. Al-Hadhrami ${ }^{2, \text { d) }}$ \\ ${ }^{1}$ Department of Environmental and Natural Resources Management, University of Ioannina, \\ Seferi 2, 30100 Agrinio, Greece \\ ${ }^{2}$ Center for Engineering Research, Research Institute, King Fahd University of Petroleum \\ and Minerals, Dhahran-31261, Saudi Arabia \\ ${ }^{3}$ Mechanical and Aeronautical Engineering Department, University of Pretoria, Pretoria, \\ South Africa
}

(Received 20 August 2011; accepted 3 February 2012; published online 24 February 2012)

\begin{abstract}
This paper utilizes three hourly measured values of wind speed and direction from seven buoys data collection stations in Aegean Sea to study the wind speed and power characteristics applying the Weibull shape and scale parameters. Specifically, the site dependent, annual and monthly mean patterns of mean wind speed, Weibull parameters, frequency distribution, most probable wind speed, maximum energy carrying wind speed, wind power density and wind energy density characteristics have been studied. The Weibull distribution was found to represent the wind speed distribution with more than $90 \%$ accuracy in most of the cases. Slightly decreasing trends were observed in annual mean wind speed values at Lesvos and increasing at Mykonos. The mean values of wind speed, scale parameter, most probable wind speed, maximum energy carrying wind speed, wind power and wind energy density values showed higher values during winter time and lower in summer time. Mykonos was found to be the best site from wind power harnessing point of view. Moreover, the correlation between the percentages of times the wind speed was above cut-in-speed and the measured mean wind speed for the three selected sites and the correlation between the aforementioned percentages and the scale parameter $\mathrm{c}$ were examined and were found linear. (C) 2012 American Institute of Physics. [doi:10.1063/1.3688030]
\end{abstract}

\section{INTRODUCTION}

Wind energy was the fastest growing energy technology in terms of percentage of yearly growth of installed capacity among the sources of renewable energy. ${ }^{1-5}$ Global wind power installations increased by $35.8 \mathrm{GW}$ in $2010,{ }^{40}$ according to the Global Wind Energy Council. This brings total installed wind energy capacity up to $194.4 \mathrm{GW}$, a $22.5 \%$ increase on the 158.7 GW installed at the end of 2009. The new capacity added in 2010 represents investments worth EUR 47.3 billion (US Dollars 65 bn). Wind energy could be supplying $22 \%$ of the world's power generation by 2030 - and $12 \%$ by 2020 , according to the most aggressive estimate on wind energy in the Global Wind Energy Outlook 2010 (GWEO 2010). ${ }^{41}$

Three reasons have led the strong growth in wind-installed generation capacity worldwide. The first reason is the growing concern and public awareness about environmental issues.

\footnotetext{
a)Electronic mail: chbagior@cc.uoi.gr. Tel.: +302641074102. Fax: +302641074176.

${ }^{b)}$ Electronic mail: pmichala@cc.uoi.gr. Tel.: +302641074102. Fax: +302641074176.

${ }^{c)}$ Electronic mail: srehman@kfupm.edu.sa.

${ }^{\mathrm{d})}$ Electronic mail: luaimalh@kfupm.edu.sa.
} 
Second, awareness about oil and gas reserves depletion and the predicted global peaking of oil production. Third, the cost reduction for wind power installations, due to the improvements in wind turbine technologies. ${ }^{1,2,6,7}$

At the southeastern part of Europe there are still a lot to be done, so wind energy can make an important contribution to the regional energy supply and security. In Greece, the utilization of renewable energy sources, and wind energy in particular, can be described as a story of high expectations, intense initial entrepreneurial interest, delays in the start-up phase of projects and, sometimes, disappointments during the implementation procedure. Still, the current situation gives reasons for some optimism and promising perspectives of the use of wind energy. ${ }^{8}$ Turkey imports nearly $70 \%$ of its energy requirements and spends $40 \%-50 \%$ of its total export income to import fuel, mainly crude oil and natural gas, despite the fact that the country has significant wind energy potential because of its geographical characteristics, such as its shoreline and mountain-valley structures. ${ }^{9}$ In Cyprus, as the country is a small island situated in the north-eastern Mediterranean, with no indigenous conventional energy sources and away from interconnected networks of electricity and gas, the use of wind energy is imperative. ${ }^{10}$ Bulgaria's wind power is set to boom over the next decade, predicting wind power will increase from the current $330 \mathrm{MW}$ installed to over $3 \mathrm{GW}$ by 2020 , meeting $13.5 \%$ of Bulgaria's electricity demand. ${ }^{11}$ Western Balkan countries have the highest energy intensities in Europe, but very little investment and priorities are being given to the increase of the efficiency. Moreover, even these countries have a high potential for developing energy production from renewable energy sources, the present situation for their utilization is not so good, as there are many constraints in all of them (political, technological, financial, legislative, educational, etc.). Renewable energy sources can make an important contribution to the regional energy supply and security. ${ }^{12}$

Wind power density is a useful way to evaluate the wind resource available at a potential site. ${ }^{13,14}$ Wind power density is directly proportional to ${ }^{15}$ : (a) the cube of the wind speed and (b) the density of the air $\rho$. Under the assumption that air density is independent of wind speed, ${ }^{15-18}$ wind power density has been estimated in the scientific literature. Considering the time dependence of only the wind speed, the estimation of the mean wind power density can be done by the wind power density probability density function by a univariate probability model and this assumption is been used thoroughly to wind turbine energy output estimation. ${ }^{15,17}$

According to the International Standard IEC 61400-12 and other international recommendations, the two-parameter Weibull probability density function is the most appropriate distribution function for wind speed data ${ }^{19-21}$ as it gives a good fit to the observed wind speed data both at surface ${ }^{22}$ and in the upper air. ${ }^{23}$

The mean energy output estimation for a wind turbine has been carried out by using the power curve of the wind turbine and the probability density function of wind speed at the time period considered. The mode of the wind power density probability density function can be used as a wind turbine design parameter, as annual energy output is usually a maximum if a wind turbine is designed for maximum aerodynamic efficiency at this mode. ${ }^{14}$ Turbine optimization for specific wind regimes and climate conditions is becoming more common as the market expands into new territories (offshore, low wind regimes) and as the technology matures. ${ }^{24}$ Consequently, the wind power probability density function is useful in both the design process of a wind turbine and in the evaluation process of the wind resource available at a potential site. $^{13,25}$

The most probable wind speed $\left(\mathrm{V}_{\mathrm{mp}}\right)$ which represents the most frequent wind speed and wind speed carrying maximum energy $\left(\mathrm{V}_{\max , \mathrm{E}}\right)$ are two significant wind speeds for wind energy estimation. ${ }^{1,26,27}$ These statistical characteristics are not directly connected to wind energy, but the efficiency of a wind turbine conversion system is closely related to these parameters and especially $V_{\text {max,E}}$, which should be as close as possible to the rated wind speed of the system.

During the last years a lot of discussion has been made concerning the renewable sourced energy potential that could be captured in the area of Eastern Mediterranean and especially in the islands of Aegean Sea. Various research works and tasks had been demonstrated trying to 
determine the maximum wind sourced energy potential in the area. ${ }^{28-31}$ It should be noted that Hellenic Centre for Marine Research-Poseidon Team has been established a fully computerized automated network that collecting observations for several meteorological parameters from seven stations mounted on buoys in Aegean area, from the database of which measurements have been used in the present study.

The present paper has as main objective to thoroughly examine the wind characteristics for many offshore locations in the area of Aegean Sea, as being an area with large differences in wind profiles, even more between two neighbouring sites, considering long range wind data from seven meteorological stations spread across this region and using the studied Weibull parameters of the area. In addition, this study attempts the assessment of the offshore wind power potential, in order to investigate the possibility of adopting wind energy for electricity generation and a classification of the most promising sites for electricity production.

\section{WIND DATA MEASUREMENTS AND SITE DESCRIPTION}

The study utilizes 3-hourly measured wind speed and wind direction data from seven buoys stations, namely Athos, E1M3A, Lesvos, Mykonos, Petrokaravo, Santorini, and Skyros in Aegean Sea. The data collection period varied between 3.1 years and 11 years as can be seen from 6th column of the Table I below. The latitude, longitude, the data collection periods are summarized in Table I and the physical locations are depicted in Figure 1.

Two types of surface buoys are used at the selected sites: Oceanor Wavescan at Athos, and E1M3A (Figure 1, locations: 1 and 2) and Oceanor SeaWatch at Lesvos, Mykonos, Petrokaravo, Santorini, and Skyros (Figure 1, locations: 3, 4, 5, 6, and 7). The anemometer used in both types of buoys is the Young 04106 (four-blade propeller anemometer).

The Aegean is connected through the straits of the Dardanelles, the Sea of Marmara, and the Bosporus to the Black Sea. It contains more than 3000 islands, with Crete its largest island and is considered the home of the earliest European civilization. The Aegean Sea covers about $214000 \mathrm{~km}^{2}$ in area, and measures about $610 \mathrm{~km}$ longitudinally and $300 \mathrm{~km}$ latitudinally. The sea's maximum depth is $3543 \mathrm{~m}$ east of Crete. North winds prevail in the Aegean Sea, although from the end of September to the end of May, during the mild winter season, these winds alternate with southwesterlies. The barometric conditions that cause these prevailing winds are the existence of both high barometric pressures over the central Balkans and low pressures over Turkey. ${ }^{29}$ The same winds blow in Cyprus as westerlies to southwesterlies, being more humid. ${ }^{28,30-34}$

The entire data set was checked for completeness and erroneous values before starting any analysis. The outliers were either deleted or in some cases were taken as the average between the two neighboring values. In case of hourly values if more than five consecutive values were missing the whole day's data was not considered. In case when three or more days' data were missing then the whole month's data were not considered in the analysis. In the present case, such cases were negligent almost none. Hence, data set used in the present work is free from erroneous values and should be considered as of high quality.

As preliminary assessment and magnitude of wind power density calculated at $50 \mathrm{~m}$ above ground level (AGL), Mykonos was classified as the superb windy site with class 7 winds and

TABLE I. Summary of site specific coordinates and wind power class.

\begin{tabular}{lccccccc}
\hline \hline Location & Latitude (N) & Longitude (E) & Start date & End date & Period (Years) & WPD $\left(\mathrm{W} / \mathrm{m}^{2}\right)$ & Wind class \\
\hline Athos & $39^{\circ} 57^{\prime} 843^{\prime \prime}$ & $24^{\circ} 43^{\prime} 208^{\prime \prime}$ & $05 / 25 / 2000$ & $12 / 31 / 2010$ & 11 & 539 & 5-Excellent \\
E1M3A & $35^{\circ} 46^{\prime} 990^{\prime \prime}$ & $24^{\circ} 54^{\prime} 880^{\prime \prime}$ & $05 / 28 / 2007$ & $01 / 01 / 2011$ & 3.6 & 493 & 4-Good \\
Lesvos & $39^{\circ} 09^{\prime} 346^{\prime \prime}$ & $25^{\circ} 48^{\prime} 42^{\prime \prime}$ & $12 / 31 / 1999$ & $01 / 01 / 2011$ & 11 & 693 & 6-Outstanding \\
Mykonos & $37^{\circ} 30^{\prime} 690^{\prime \prime}$ & $25^{\circ} 27^{\prime} 494^{\prime \prime}$ & $12 / 31 / 1999$ & $01 / 01 / 2011$ & 11 & 971 & 7-Superb \\
Petrokaravo & $37^{\circ} 35^{\prime} 915^{\prime \prime}$ & $23^{\circ} 33^{\prime} 715^{\prime \prime}$ & $08 / 28 / 2007$ & $01 / 01 / 2011$ & 3.3 & 368 & 3-Fair \\
Santorini & $36^{\circ} 15^{\prime} 510^{\prime \prime}$ & $25^{\circ} 29^{\prime} 769^{\prime \prime}$ & $12 / 31 / 1999$ & $01 / 01 / 2011$ & 11 & 590 & 5-Excellent \\
Skyros & $39^{\circ} 06^{\prime} 360^{\prime \prime}$ & $24^{\circ} 27^{\prime} 568^{\prime \prime}$ & $08 / 28 / 2007$ & $01 / 01 / 2011$ & 3.3 & 540 & 5-Excellent \\
\hline \hline
\end{tabular}




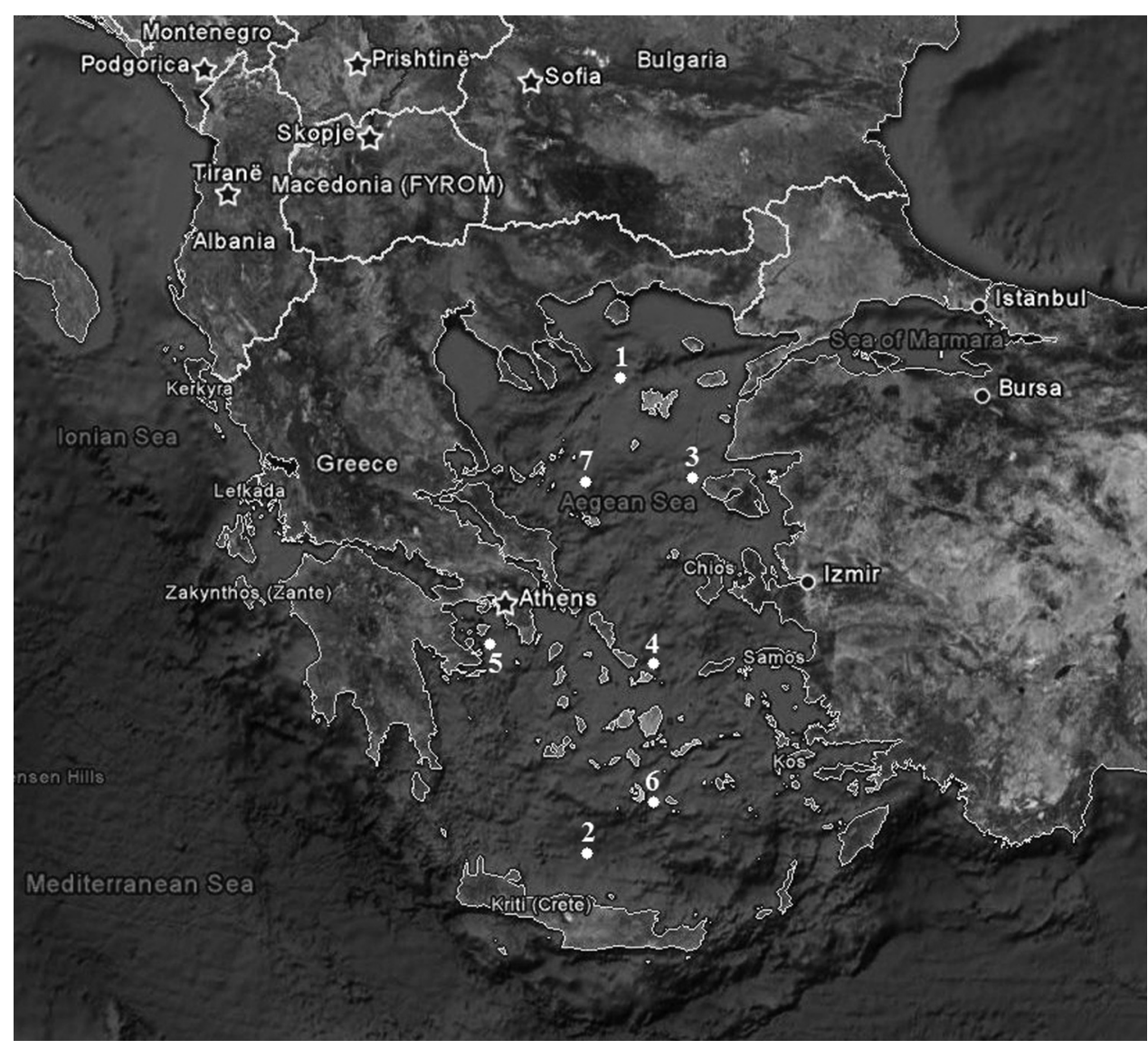

FIG. 1. Map of Aegean Sea with the sites of the buoys: (1) Athos, (2) E1M3A, (3) Lesvos, (4) Mykonos, (5) Petrokaravo, (6) Santorini, and (7) Skyros.

wind power density of $971 \mathrm{~W} / \mathrm{m}^{2}$. Petrokaravo, with wind power densities of $368 \mathrm{~W} / \mathrm{m}^{2}$, was classified as the fair windy site with wind power class of 3 , as mentioned in the last column of Table I. All the other sites were found to be between good to outstanding.

\section{WIND SPEED ESTIMATION AT HUB HEIGHT}

Today's modern wind turbines and especially the offshore ones have hub heights of $100 \mathrm{~m}$ and more, while the wind measurements are usually made at 10 to $40 \mathrm{~m}$ above ground level in case of onshore measurements and around $10 \mathrm{~m}$ above water surface level in case of offshore measurements. To estimate the wind speed accurately at hub height and then the energy yield from an offshore wind turbine, the local wind shear exponent is required. Usually, the wind shear exponent could be estimated using wind measurements at two or three heights above ground level. In the present case, the wind measurements were made at 3 and $10 \mathrm{~m}$ above water surface level. The wind shear exponent was calculated using the power law fit, as shown in Figures 2(a) and 2(b), for Athos and E1M3A buoys stations, respectively. The wind shear exponent was also estimated for all the locations used in this study and was found to be 0.123 . The same value for all locations is justified, since all buoys are in water and it is a uniform area, having same roughness, so the wind shear has to be same.

The wind speed was calculated at hub height using wind shear exponent value of 0.123 and the following equation: ${ }^{35,36}$

$$
V_{2}=V_{1}\left(\frac{Z_{2}}{Z_{1}}\right)^{a}
$$



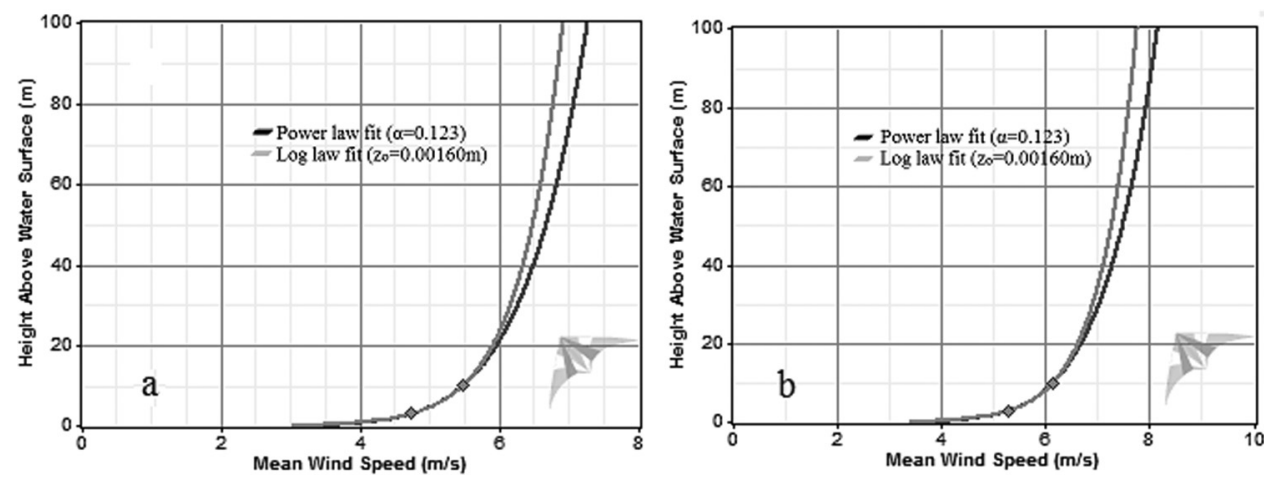

FIG. 2. Wind shear for Athos (a) and E1M3A (b).

where $V_{1}$ and $V_{2}$ are the wind speeds at height $Z_{1}$ and $Z_{2}$, respectively, and $\alpha$ is the wind shear exponent.

\section{WIND DATA ANALYSIS METHODOLOGY}

\section{A. Weibull shape and scale parameters estimation}

The maximum likelihood method fits a Weibull distribution to a set of measured wind speeds. This method employs the following equation (Stevens and Smulders, ${ }^{37}$ ) for the calculation of shape parameter $(\mathrm{k})$, using an iterative process:

$$
k=\left(\frac{\sum_{i=1}^{N} V_{i}^{k} \ln \left(V_{i}\right)}{\sum_{i=1}^{N} V_{i}^{k}}-\frac{\sum_{i=1}^{N} \ln \left(V_{i}\right)}{N}\right)^{-1},
$$

where $V_{i}$ is the wind speed in time step i and $N$ is the number of time steps. Once the shape parameter $\mathrm{k}$ has been determined, the following equation could be used to calculate the value of scale parameter $\mathrm{c}$ :

$$
c=\left(\frac{\sum_{i=1}^{N} V_{i}^{k}}{N}\right)^{\frac{1}{k}}
$$

\section{B. Most probable wind speed}

The most probable wind speed simply provides the most frequently occurring win speed for a given wind probability distribution. The most probable wind speed can be calculated using the Weibull shape and scale parameters via the following equation: ${ }^{27}$

$$
V_{m p}=c\left(1-\frac{1}{k}\right)^{\frac{1}{k}}
$$

\section{Maximum energy carrying wind speed estimation}

The maximum energy carrying wind speed is the speed which generates maximum energy. This can be estimated from the Weibull parameters through the following relationship reported in Ref. 38:

$$
V_{\max , E}=c\left(1+\frac{2}{k}\right)^{\frac{1}{k}}
$$


TABLE II. Summary of Weibull parameters, most probable and maximum energy carrying wind speed at seven locations at $10 \mathrm{~m}$ above water surface.

\begin{tabular}{lrrrrrrr}
\hline \hline Parameters & \multicolumn{1}{c}{ Athos } & E1M3A & Lesvos & Mykonos & Petrokaravo & Santorini & Skyros \\
\hline $\mathrm{V}(\mathrm{m} / \mathrm{s})$ & 5.08 & 6.09 & 6.29 & 7.45 & 5.31 & 6.34 & 5.88 \\
$\sigma$ & 3.96 & 3.18 & 3.93 & 4.12 & 3.19 & 3.50 & 3.67 \\
$\mathrm{~K}$ & 1.24 & 1.99 & 1.62 & 1.78 & 1.72 & 1.82 & 1.70 \\
$\mathrm{c}(\mathrm{m} / \mathrm{s})$ & 4.78 & 6.83 & 6.38 & 7.90 & 5.89 & 6.96 & 6.40 \\
$\mathrm{~V}_{\mathrm{mp}}(\mathrm{m} / \mathrm{s})$ & 1.27 & 4.81 & 3.53 & 4.97 & 3.55 & 4.49 & 3.80 \\
$\mathrm{~V}_{\max , \mathrm{E}}(\mathrm{m} / \mathrm{s})$ & 10.37 & 9.69 & 10.48 & 12.06 & 9.22 & 10.46 & 10.11 \\
$\mathrm{WPD}\left(\mathrm{Wm}{ }^{2}\right)$ & 134.08 & 58.91 & 142.23 & 165.07 & 64.45 & 91.28 & 98.32 \\
$\mathrm{WED}\left(\mathrm{kWh} / \mathrm{m}^{2}\right)$ & 1174.52 & 516.06 & 1245.96 & 1445.99 & 564.58 & 799.62 & 861.32 \\
\hline \hline
\end{tabular}

\section{Wind power density estimation}

The wind power density is directly proportional to the cube of mean wind speed (V) and the air density $(\rho)$ and can be calculated using the following relationship reported in Ref. 39:

$$
W P D=\frac{1}{2} \rho V^{3} .
$$

The wind power density can also be calculated using the Weibull distribution function as follows: ${ }^{32}$

$$
W P D=\int_{0}^{\infty} \frac{1}{2} \rho V^{3} f(V) d V=\frac{1}{2} \rho c^{3} \Gamma\left(\frac{k+3}{k}\right)
$$

where $\rho$ is the standard air density at mean sea temperature of $15^{\circ} \mathrm{C}$, and 1 atmospheric pressure that is $1.225 \mathrm{~kg} / \mathrm{m}^{3}$.

\section{E. Wind energy density estimation}

Once the wind power density (WPD) has been estimated, the wind energy density can be obtained just multiplying by the number of hours (T). To get the annual wind energy density, one can multiply WPD by $8760 \mathrm{~h}$ to get the wind energy density in $\mathrm{kWh} / \mathrm{m}^{2}$,

$$
W E D=\frac{1}{2} \rho c^{3} \Gamma\left(\frac{k+3}{k}\right) T .
$$

TABLE III. Variation of mean wind speed, Weibull shape parameter and Weibull scale parameter at 10 and $90 \mathrm{~m}$ above water surface, at seven locations.

\begin{tabular}{lccccccc}
\hline \hline & \multicolumn{3}{c}{$10 \mathrm{~m}$} & & \multicolumn{3}{c}{$90 \mathrm{~m}$} \\
\cline { 2 - 3 } & $\mathrm{V}_{\text {mean }}(\mathrm{m} / \mathrm{s})$ & $\mathrm{k}$ & $\mathrm{c}(\mathrm{m} / \mathrm{s})$ & & $\mathrm{V}_{\text {mean }}(\mathrm{m} / \mathrm{s})$ & $\mathrm{k}$ & $\mathrm{c}(\mathrm{m} / \mathrm{s})$ \\
\hline Athos & 5.08 & 1.24 & 4.78 & & 6.65 & 1.25 & 6.27 \\
E1M3A & 6.09 & 1.99 & 6.83 & & 7.99 & 1.99 & 8.95 \\
Lesvos & 6.29 & 1.62 & 6.38 & & 8.25 & 1.62 & 8.37 \\
Mykonos & 7.45 & 1.78 & 7.90 & & 9.76 & 1.78 & 10.36 \\
Petrokaravo & 5.31 & 1.72 & 5.89 & & 6.96 & 1.72 & 7.72 \\
Santorini & 6.34 & 1.82 & 6.96 & & 8.31 & 1.82 & 9.12 \\
Skyros & 5.88 & 1.70 & 6.40 & & 7.71 & 1.70 & 8.38 \\
\hline \hline
\end{tabular}




\section{RESULTS AND DISCUSSION}

The three hourly measured wind speed data from seven buoys stations in Aegean Sea was used to obtain the site dependent, annual and monthly statistics of wind speed. These overall, annual and monthly mean values were then used to calculate the Weibull parameters which in turn were used to estimate the most probable, maximum energy carrying wind speed, wind power density, and finally the wind energy density for all the stations used in the present work. The obtained statistics and other characteristics are discussed in Subsections V A-V D below.
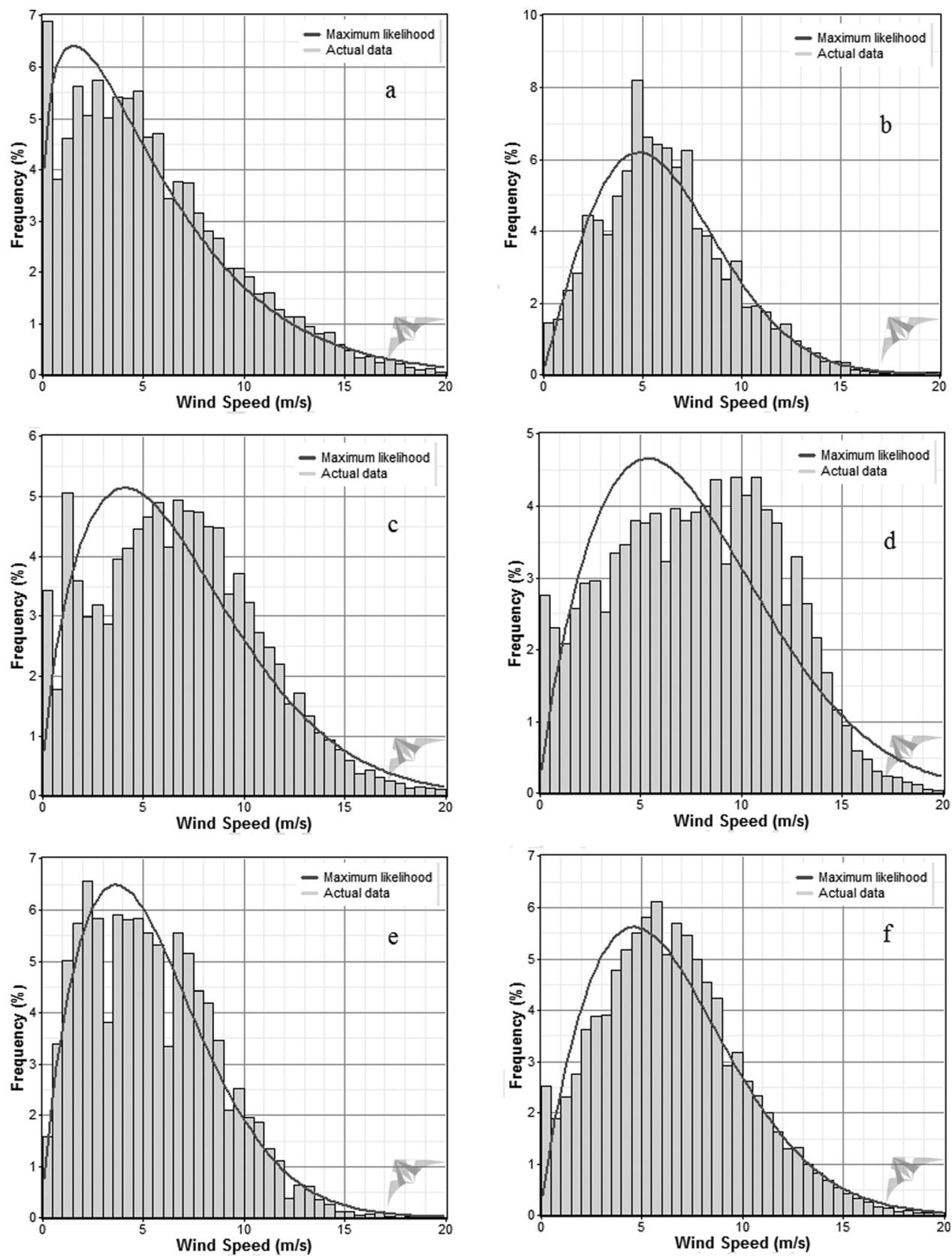

FIG. 3. Comparison of Weibull fit with measured wind speed frequency distribution at $10 \mathrm{~m}$, at Athos (a), E1M3A (b), Lesvos (c), Mykonos (d), Petrokaravo (e), and Santorini (f). 


\section{A. Site dependent statistics of wind characteristics}

The overall mean wind speed, the standard deviation, Weibull shape and scale parameters, the most probable and maximum energy carrying wind speeds, wind power density and wind energy density values are summarized in Table II.

The maximum wind speed of $7.45 \mathrm{~m} / \mathrm{s}$ at $10 \mathrm{~m}$ above water surface level was found at Mykonos and the minimum of $5.08 \mathrm{~m} / \mathrm{s}$ and $5.31 \mathrm{~m} / \mathrm{s}$ at Athos and Petrokaravo, respectively, while at all remaining locations the wind speed was more than $5.88 \mathrm{~m} / \mathrm{s}$. The shape parameter values were around $1.5 \pm 0.25$ at all the locations, except Athos. The scale parameter value was more than $5.89 \mathrm{~m} / \mathrm{s}$ for all the stations except at Athos where it was $4.78 \mathrm{~m} / \mathrm{s}$. At Mykonos, the most probable wind speed was found to be $4.97 \mathrm{~m} / \mathrm{s}$, while at Athos it was only 1.27 . This simply means that Mykonos receives higher wind speed for most of the times while Athos the least. The maximum energy carrying wind speed, $V_{\max , \mathrm{E}}$, was highest at Mykonos $(12.06 \mathrm{~m} / \mathrm{s})$ and the minimum at Petrokaravo $(9.22 \mathrm{~m} / \mathrm{s})$. This implies that a wind speed of $10.37 \mathrm{~m} / \mathrm{s}$ at Athos produced the maximum energy and so on.

The observed discrepancies of the results at these two locations are relatively justified from the existence of the prevailing winds in Aegean Sea, called Etesians, which are the strong, dry north winds, from about mid-May to mid-September. Even these winds cover the whole Aegean area, in the Northern Aegean Sea (Athos area), especially the Etesians blow as winds of
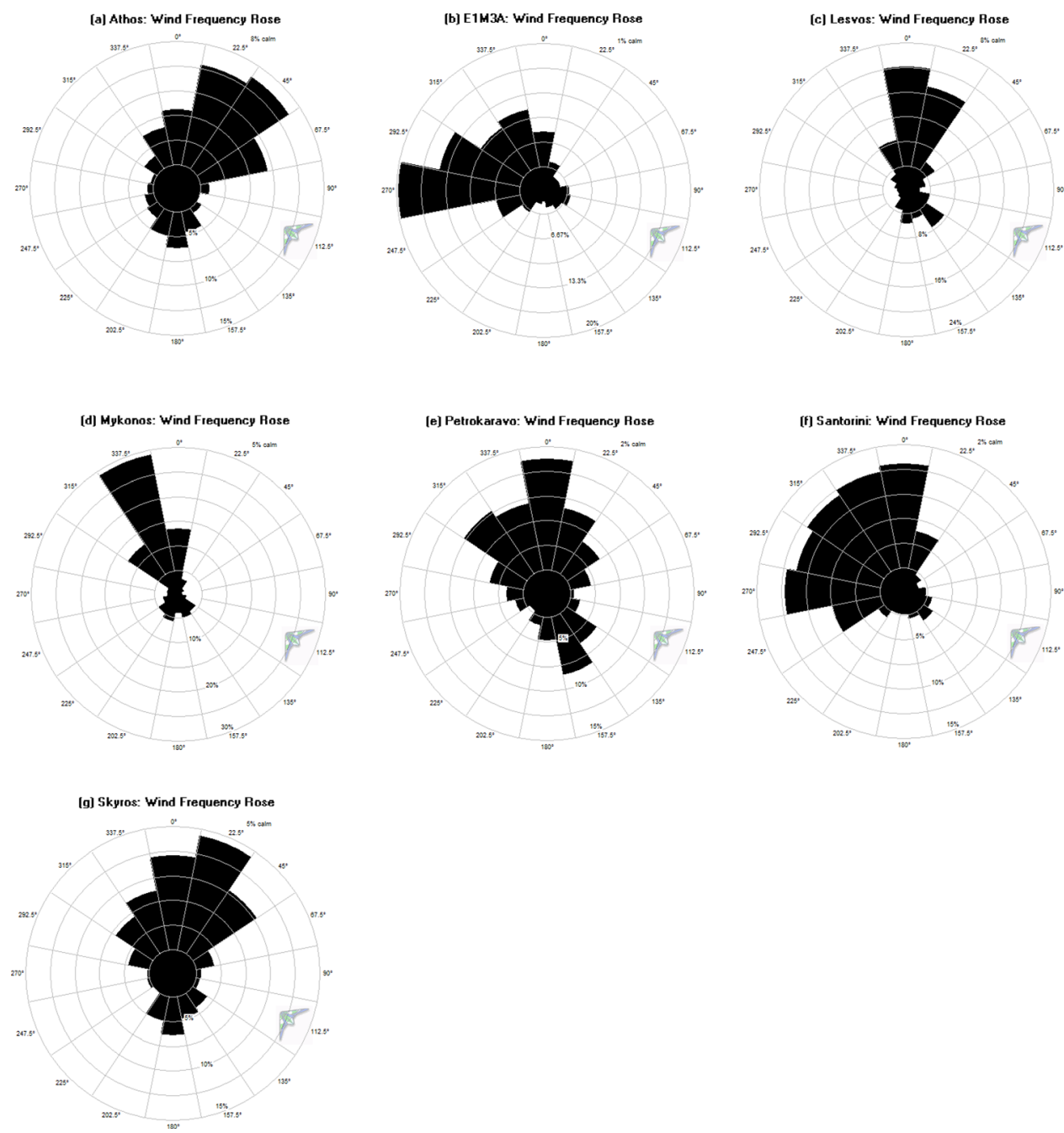

FIG. 4. Wind frequency roses for all the selected stations. 
Percentage of times and mean wind speed

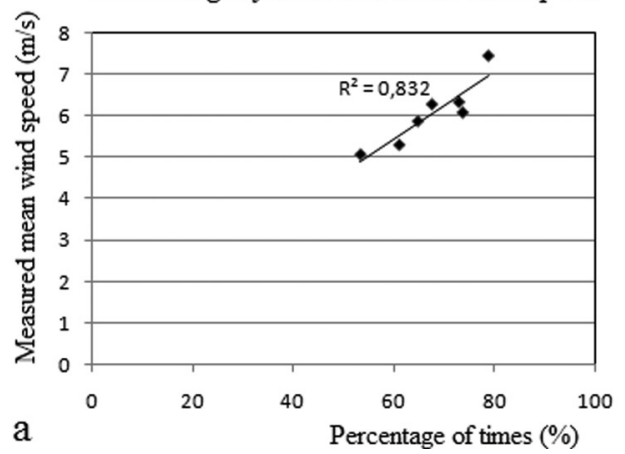

Percentage of times and scale parameter

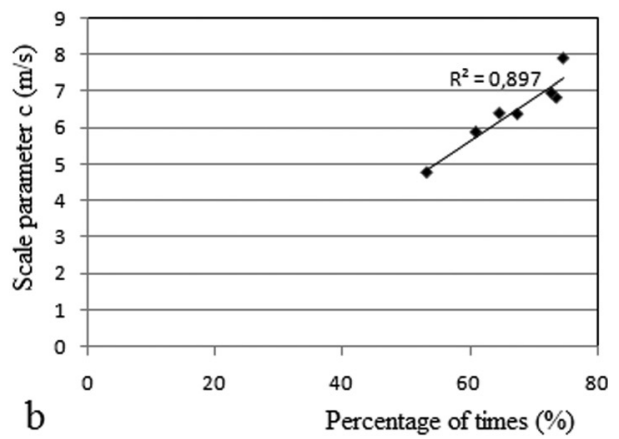

FIG. 5. Correlation between the percentages of times the wind speed was above cut-in-speed and (a) the measured mean wind speed values (b) the scale parameter values, for the seven selected stations.

northeasterly to northerly direction. Given the local topography of the land relief at the north of the buoy (Athos mountain-over $2000 \mathrm{~m}$ ), there is a screening effect to these strong winds. This effect doesn't happen in the case of Mykonos buoy (in the central Aegean, these winds blow of northerly direction also, but there is no hindrance in the area).

The mean wind speed was extrapolated to $90 \mathrm{~m}$ in steps of $20 \mathrm{~m}$ using the measured wind speed at 3 and $10 \mathrm{~m}$, the local wind shear exponent $\alpha=0.123$, and the Eq. (1). The mean wind speed at Athos was $31 \%$ higher at $90 \mathrm{~m}(6.65 \mathrm{~m} / \mathrm{s})$ than that at $10 \mathrm{~m}(5.08 \mathrm{~m} / \mathrm{s})$, as can be seen from Table III below. The increase in wind speed was almost $31 \%$ in all the cases shown in this table.

The Weibull shape parameter values were almost the same at $10 \mathrm{~m}$ and $90 \mathrm{~m}$, as can be seen from Table III. At $10 \mathrm{~m}$, the maximum value of $\mathrm{k}$ of 1.99 was at E1M3A station while minimum of 1.24 at Athos. Moreover, the scale parameter values at 10 and $90 \mathrm{~m}$ above water surface level are compared in Table III. Almost similar trends are observed as in case of mean wind speed shown in the aforementioned table.

The frequency distribution obtained using the Weibull parameters and the measured wind speed are compared in Figure 3 for six buoys stations. In general, there was an excellent agreement between the estimated and measured frequency distribution but in case of Athos, Lesvos, and Mykonos the higher differences were observed between the two at wind speeds less than $5 \mathrm{~m} / \mathrm{s}$. At higher wind speeds, the agreement between the Weibull parameter based frequency

TABLE IV. Annual variation of Weibull shape and scale parameters.

\begin{tabular}{|c|c|c|c|c|c|c|c|c|c|c|c|c|c|c|}
\hline \multirow[b]{2}{*}{ Year } & \multicolumn{2}{|c|}{ Athos } & \multicolumn{2}{|c|}{ E1M3A } & \multicolumn{2}{|c|}{ Lesvos } & \multicolumn{2}{|c|}{ Mykonos } & \multicolumn{2}{|c|}{ Petrokaravo } & \multicolumn{2}{|c|}{ Santorini } & \multicolumn{2}{|c|}{ Skyros } \\
\hline & K & $\mathrm{c}(\mathrm{m} / \mathrm{s})$ & $\mathrm{k}$ & $\mathrm{c}(\mathrm{m} / \mathrm{s})$ & $\mathrm{k}$ & $\mathrm{c}(\mathrm{m} / \mathrm{s})$ & $\mathrm{k}$ & $\mathrm{c}(\mathrm{m} / \mathrm{s})$ & $\mathrm{k}$ & $\mathrm{c}(\mathrm{m} / \mathrm{s})$ & $\mathrm{k}$ & $\mathrm{c}(\mathrm{m} / \mathrm{s})$ & $\mathrm{k}$ & $\mathrm{c}(\mathrm{m} / \mathrm{s})$ \\
\hline 2000 & & & & & 1.70 & 7.74 & & & & & 1.66 & 7.47 & & \\
\hline 2001 & 0.81 & 4.64 & & & & & 1.55 & 8.83 & & & 1.78 & 7.66 & & \\
\hline 2002 & & & & & 1.48 & 7.23 & 1.41 & 7.61 & & & 1.43 & 6.62 & & \\
\hline 2003 & & & & & 1.36 & 6.70 & & & & & & & & \\
\hline 2004 & 1.04 & 5.24 & & & 1.57 & 7.60 & 1.66 & 8.39 & & & 2.02 & 7.47 & & \\
\hline 2005 & 1.70 & 7.49 & & & & & 1.66 & 7.86 & & & 1.87 & 7.30 & & \\
\hline 2006 & 1.58 & 6.16 & & & 1.66 & 7.45 & & & & & 1.69 & 6.61 & & \\
\hline 2007 & 1.47 & 6.01 & & & 1.58 & 6.46 & 1.87 & 8.32 & & & 2.00 & 7.36 & & \\
\hline 2008 & 1.53 & 6.42 & 1.82 & 6.87 & & & 2.02 & 8.88 & 1.66 & 6.06 & 1.87 & 6.82 & 1.82 & 7.37 \\
\hline 2009 & & & & & & & 2.11 & 8.80 & 1.75 & 5.94 & 0.93 & 4.97 & 1.77 & 6.94 \\
\hline 2010 & 1.57 & 6.85 & & & 1.84 & 7.77 & 1.87 & 8.28 & & & 1.97 & 7.28 & 1.55 & 6.43 \\
\hline
\end{tabular}


and measured frequency distribution was superb with less than 5\% deviation. At Athos, a close agreement between the Weibull distribution function and the measured wind speed was obtained with $\mathrm{R}^{2}=0.90$. At E1M3A, Lesvos, Mykonos, Petrokaravo, Santorini, and Skyros the $\mathrm{R}^{2}$ values were $0.94,0.79,0.70,0.92,0.93$, and 0.94 , respectively. This exercise proved that the Weibull distribution can be used to represent the wind speed distribution with sufficient accuracy.

At Athos, the wind speed was above cut-in-speed of $4 \mathrm{~m} / \mathrm{s}$ for $53.31 \%$ of the times during the data collection period and the predominantly blown from NS $(>45 \%)$. At E1M3A, the remained above cut-in-speed for more than $73.61 \%$ of the times and came from WN directions for $50 \%$ of the times. At Lesvos, Mykonos, and Petrokaravo, the wind remained above cut-inspeed for more than $67.5 \%, 78.68 \%$, and $61.01 \%$ of the times and was found to be blowing predominantly from NE, N-NS-NE, and NW, respectively. At remaining two stations, the wind speed remained above cut-in-speed for more than $72.86 \%$ and $64.68 \%$ of the times. The wind direction was mostly found to be from $\mathrm{N}$, as can be seen from Figure 4. Moreover, in all
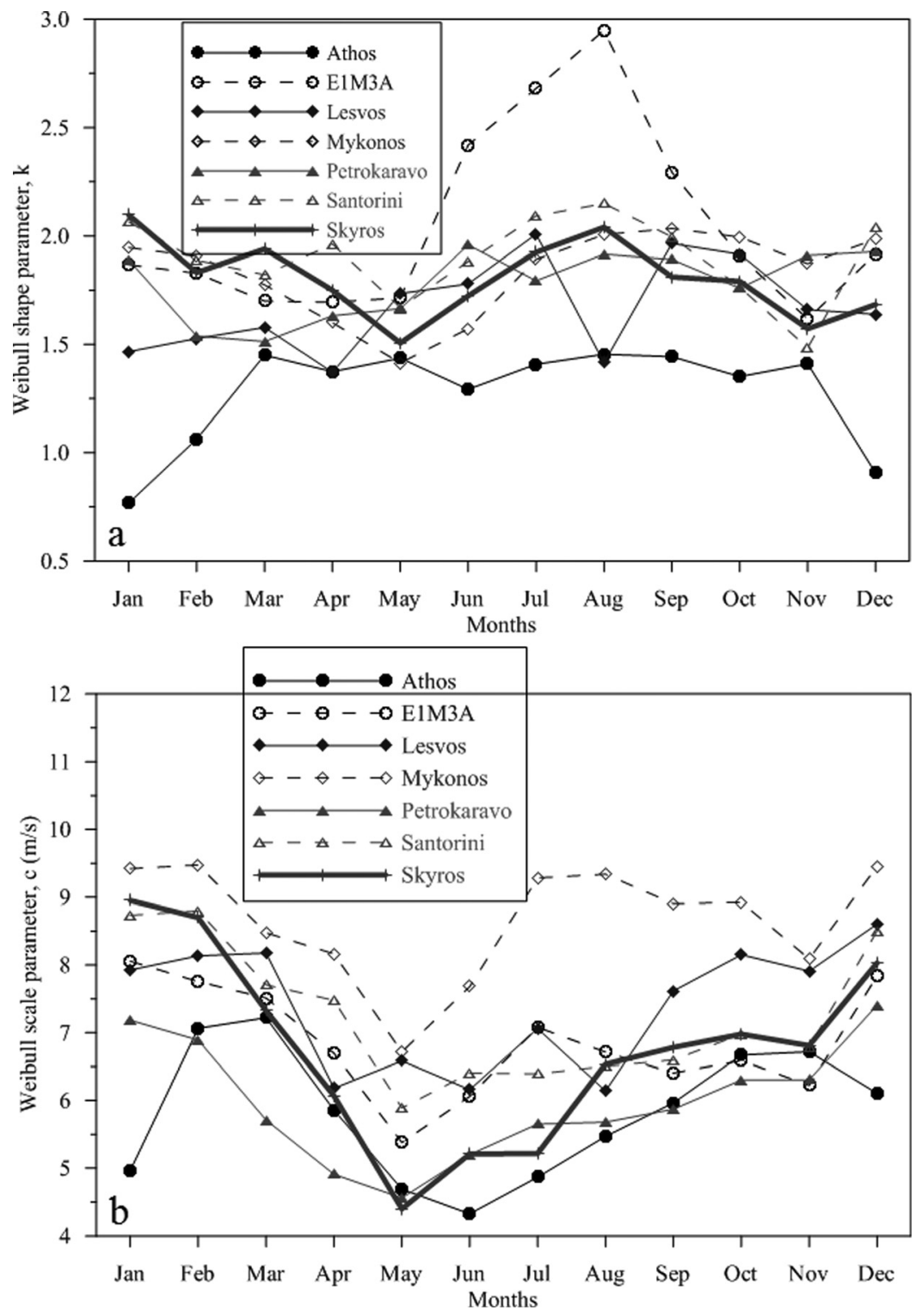

FIG. 6. Seasonal variation of Weibull shape parameter k (a) and Weibull scale parameter c (b), for all the locations. 
stations, a strong linear relation was found between the percentages of times the wind speed was above cut-in-speed and the mean wind speed values, as the scale parameter values, as well (Figures 5(a) and 5(b), respectively). The values of $\mathrm{R}^{2}$ are relatively high and demonstrate a remarkable match of the linear model $\left(\mathrm{R}^{2}=0.832\right.$ and 0.897 , respectively).

\section{B. Annual and monthly variation of Weibull parameters}

The annual mean values of shape parameter $\mathrm{k}$ were found 2 to greater than 2 at Mykonos in the years 2008 and 2009 and Santorini in 2004, 2007, 2008, and 2010, as given in Table IV.

In most of the cases the $\mathrm{k}$ values were in the range of $1.5 \pm 0.25$. The annual scale parameter values were found to be highest at Mykonos and lowest at Athos. At Athos, an increasing trend was observed in the values of c from 2001 to 2010 but slightly decreasing Lesvos. At Mykonos, an upward trend was observed while at Santorini a mixed signal was received. These trends have to be verified with long-term annual mean values from the nearby historical meteorological stations.

The monthly mean values of shape parameter showed higher values in the summer time and lower in the winter time in general with highest in August as can be seen from Figure 6(a). Larger seasonal ranges were observed at Athos and E1M3A stations in $\mathrm{k}$ values as depicted in Figure 6(a). The scale parameter values showed a bell shaped trend starting high from January and reaching a minimum in June and then again increasing towards end of the year, as shown in Figure 6(b). Highest seasonal change in scale parameter values was observed at Skyros.

\section{Annual and monthly variation of most probable and maximum energy carrying wind speed}

The most probable wind speed was minimum of $0.22 \mathrm{~m} / \mathrm{s}$ in 2004 and maximum of $4.43 \mathrm{~m} / \mathrm{s}$ in 2005 at Athos, as summarized in Table V. At Lesvos, the $\mathrm{V}_{\mathrm{mp}}$ values varied between a minimum of $2.54 \mathrm{~m} / \mathrm{s}$ and $5.09 \mathrm{~m} / \mathrm{s}$ corresponding to 2003 and 2010, respectively. At both of these sites, no definite increasing or decreasing trends could be detective over the data reporting period. At Mykonos a definite increasing trend was observed from 2005 onwards but a mixed trend at Santorini. The most probable wind speed provides information about the most occurring value of wind speed during the data collection period. For example, at Athos, in year 2004, $0.22 \mathrm{~m} / \mathrm{s}$ wind speed was most prevalent while in $2005,4.43 \mathrm{~m} / \mathrm{s}$.

A large variation was observed in $\mathrm{V}_{\text {max,E }}$ values at Athos i.e., 10.35 in 2006 and 21.6 in 2000. At Lesvos the values were almost the same during entire data reporting period while at

TABLE V. Annual variation of most probable and maximum energy carrying wind speed in $\mathrm{m} / \mathrm{s}$.

\begin{tabular}{|c|c|c|c|c|c|c|c|c|c|c|c|c|c|c|}
\hline \multirow[b]{2}{*}{ Year } & \multicolumn{2}{|c|}{ Athos } & \multicolumn{2}{|c|}{ E1M3A } & \multicolumn{2}{|c|}{ Lesvos } & \multicolumn{2}{|c|}{ Mykonos } & \multicolumn{2}{|c|}{ Petrokaravo } & \multicolumn{2}{|c|}{ Santorini } & \multicolumn{2}{|c|}{ Skyros } \\
\hline & $\mathrm{V}_{\mathrm{mp}}$ & $\mathrm{V}_{\max , \mathrm{E}}$ & $\mathrm{V}_{\mathrm{mp}}$ & $\mathrm{V}_{\max , \mathrm{E}}$ & $\mathrm{V}_{\mathrm{mp}}$ & $\mathrm{V}_{\max , \mathrm{E}}$ & $\mathrm{V}_{\mathrm{mp}}$ & $\mathrm{V}_{\max , \mathrm{E}}$ & $\mathrm{V}_{\mathrm{mp}}$ & $\mathrm{V}_{\max , \mathrm{E}}$ & $\mathrm{V}_{\mathrm{mp}}$ & $\mathrm{V}_{\max , \mathrm{E}}$ & $\mathrm{V}_{\mathrm{mp}}$ & $\mathrm{V}_{\max , \mathrm{E}}$ \\
\hline 2000 & & & & & 4.60 & 12.21 & & & & & 4.28 & 12.02 & & \\
\hline 2001 & 0.78 & 21.60 & & & & & 4.53 & 15.06 & & & 4.94 & 11.60 & & \\
\hline 2002 & & & & & 3.38 & 12.90 & 3.19 & 14.19 & & & 2.89 & 12.13 & & \\
\hline 2003 & & & & & 2.54 & 12.99 & & & & & & & & \\
\hline 2004 & 0.22 & 14.74 & & & 4.00 & 12.79 & 4.80 & 13.54 & & & 5.33 & 10.48 & & \\
\hline 2005 & 4.43 & 11.86 & & & & & 4.50 & 12.67 & & & 4.91 & 10.69 & & \\
\hline 2006 & 3.25 & 10.35 & & & 4.26 & 12.02 & & & & & 3.89 & 10.45 & & \\
\hline 2007 & 2.74 & 10.81 & & & 3.43 & 10.83 & 5.54 & 12.26 & & & 5.29 & 10.36 & & \\
\hline 2008 & 3.20 & 11.10 & 4.43 & 10.32 & & & 6.34 & 12.48 & 3.48 & 9.77 & 4.98 & 9.84 & 4.75 & 11.08 \\
\hline 2009 & & & & & & & 6.48 & 12.08 & 3.67 & 9.16 & 4.43 & 10.34 & 4.35 & 10.63 \\
\hline 2010 & 3.61 & 11.54 & & & 5.09 & 11.58 & 5.48 & 12.23 & & & 5.51 & 10.18 & 3.31 & 10.95 \\
\hline
\end{tabular}



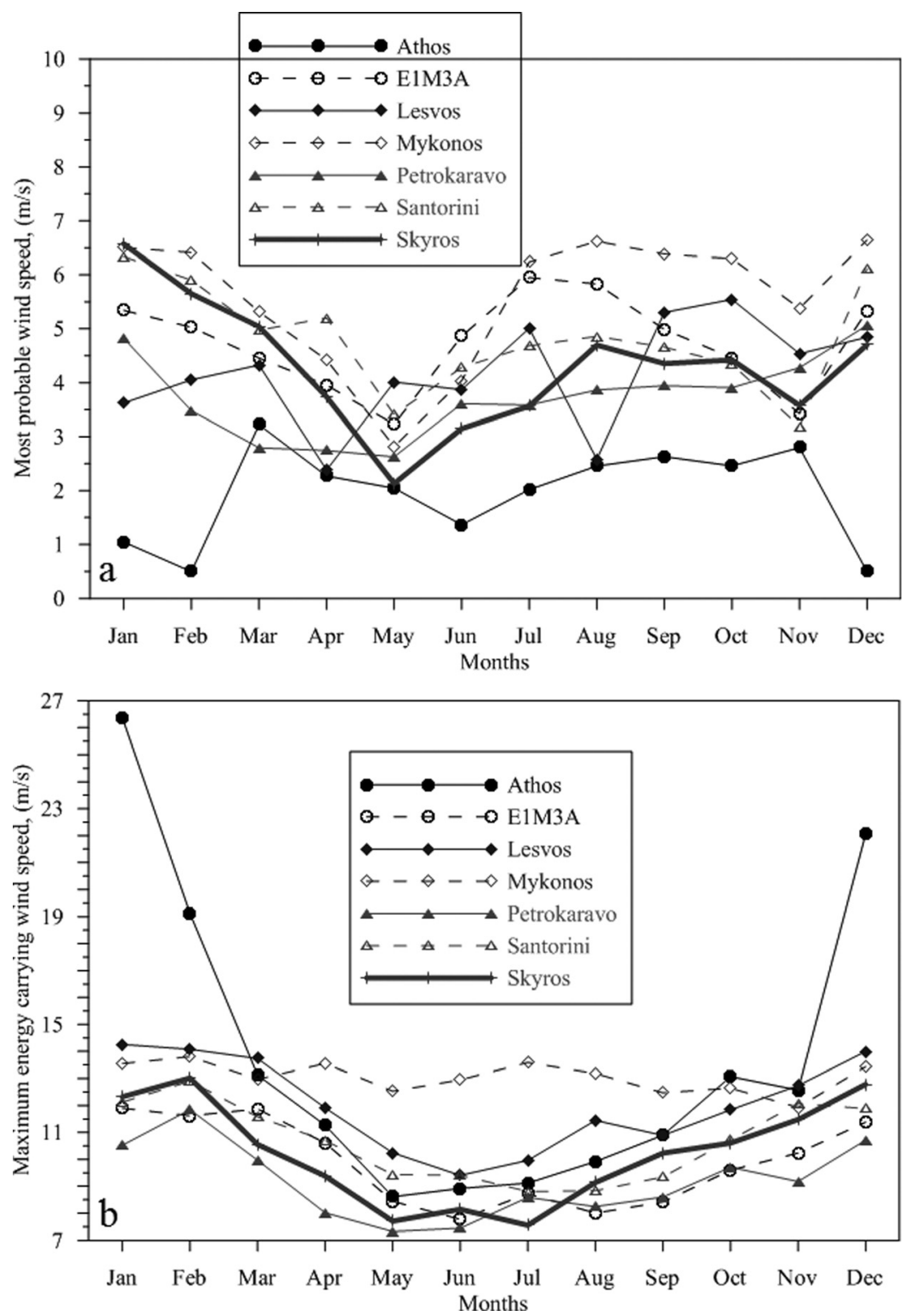

FIG. 7. Seasonal variation of most probable wind speed (a) and maximum energy carrying wind speed (b), for all the locations.

Mykonos some variations were noticed during 2001 to 2004. At Santorini, the $\mathrm{V}_{\max , \mathrm{E}}$ values were almost the same, as can be seen from Table V. The maximum energy carrying wind speed represents the value which yields the maximum energy. For example, at Mykonos, in 2001, $\mathrm{V}_{\max , \mathrm{E}}=15.06 \mathrm{~m} / \mathrm{s}$, was responsible for giving the maximum energy while in 2007, $\mathrm{V}_{\mathrm{max}, \mathrm{E}}=12.26 \mathrm{~m} / \mathrm{s}$ produced the maximum energy.

The seasonal variation of $\mathrm{V}_{\mathrm{mp}}$ and $\mathrm{V}_{\mathrm{max}, \mathrm{E}}$ is shown in Figures 7 (a) and 7(b), respectively.

Overall, higher values of $\mathrm{V}_{\mathrm{mp}}$ were observed during winter months and lower during summer time, as shown in Figure 7(a). Highest seasonal change (2 to 6.5) was observed at Skyros. Least seasonal variations were observed at Petrokaravo and Santirini stations. Abnoramally high seasonal change in maximum energy carrying wind speed, $\mathrm{V}_{\max , \mathrm{E}}$, was observed at Athos while at other locations the seasonal change was between 7 and $14 \mathrm{~m} / \mathrm{s}$, as can be seen from Figure 7(b). Least seasonal variations were observed at Mykonos which means that energy produced at this station will be at steady rate. Usually, higher values of $\mathrm{V}_{\max , \mathrm{E}}$ were obtained during winter months and lower during summer time. 
TABLE VI. Annual variation of wind power density at seven locations.

\begin{tabular}{|c|c|c|c|c|c|c|c|}
\hline Year & $\begin{array}{l}\text { Athos } \\
\text { W/m }\end{array}$ & $\begin{array}{l}\text { E1M3A } \\
\mathrm{W} / \mathrm{m}^{2}\end{array}$ & $\begin{array}{l}\text { Lesvos } \\
\mathrm{W} / \mathrm{m}^{2}\end{array}$ & $\begin{array}{l}\text { Mykonos } \\
\mathrm{W} / \mathrm{m}^{2}\end{array}$ & $\begin{array}{c}\text { Petrokaravo } \\
\mathrm{W} / \mathrm{m}^{2}\end{array}$ & $\begin{array}{l}\text { Santorini } \\
\mathrm{W} / \mathrm{m}^{2}\end{array}$ & $\begin{array}{l}\text { Skyros } \\
W / m^{2}\end{array}$ \\
\hline 2000 & & & 137.66 & & & 133.37 & \\
\hline 2001 & 167.85 & & & 267.15 & & 111.45 & \\
\hline 2002 & & & 166.88 & 218.01 & & 137.13 & \\
\hline 2003 & & & 162.99 & & & & \\
\hline 2004 & 145.83 & & 163.42 & 190.58 & & 69.08 & \\
\hline 2005 & 126.49 & & & 156.22 & & 82.59 & \\
\hline 2006 & 86.44 & & 133.47 & & & 86.48 & \\
\hline 2007 & 97.86 & & 99.14 & 126.40 & & 66.77 & \\
\hline 2008 & 106.75 & 78.11 & & 117.06 & 71.47 & 57.91 & 96.79 \\
\hline 2009 & & & & 97.38 & 56.85 & 78.65 & 87.79 \\
\hline 2010 & 119.91 & & 108.89 & 126.11 & & 57.34 & 102.58 \\
\hline
\end{tabular}
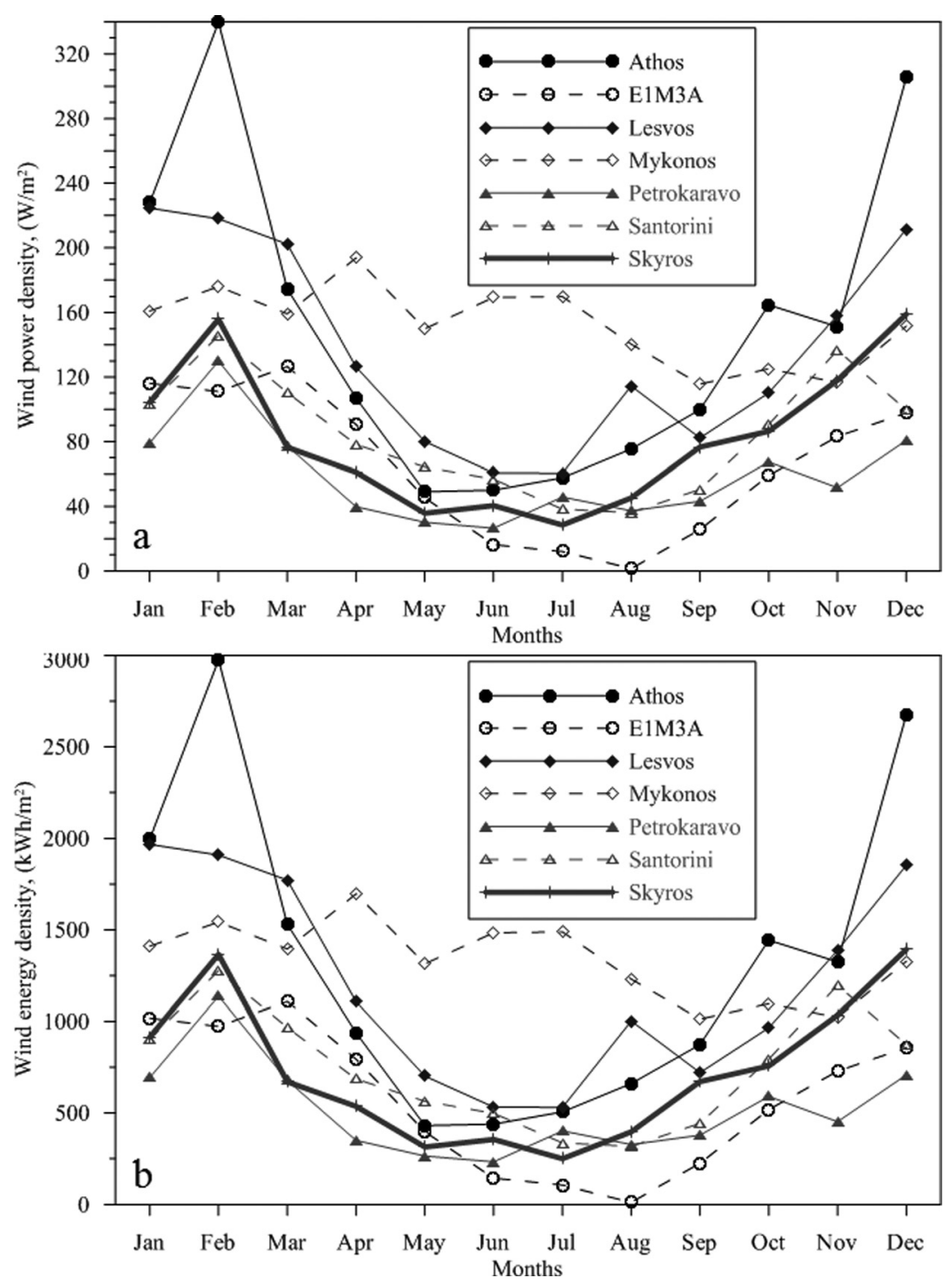

FIG. 8. Seasonal variation of wind power density (a) and wind energy density (b), for all the locations. 
TABLE VII. Annual variation of wind energy density at seven locations.

\begin{tabular}{|c|c|c|c|c|c|c|c|}
\hline Year & $\begin{array}{c}\text { Athos } \\
\mathrm{kWh} / \mathrm{m}^{2}\end{array}$ & $\begin{array}{l}\text { E1M3A } \\
\mathrm{kWh} / \mathrm{m}^{2}\end{array}$ & $\begin{array}{c}\text { Lesvos } \\
\mathrm{kWh} / \mathrm{m}^{2}\end{array}$ & $\begin{array}{l}\text { Mykonos } \\
\mathrm{kWh} / \mathrm{m}^{2}\end{array}$ & $\begin{array}{c}\text { Petrokaravo } \\
\mathrm{kWh} / \mathrm{m}^{2}\end{array}$ & $\begin{array}{l}\text { Santorini } \\
\mathrm{kWh} / \mathrm{m}^{2}\end{array}$ & $\begin{array}{c}\text { Skyros } \\
\mathrm{kWh} / \mathrm{m}^{2}\end{array}$ \\
\hline 2000 & & & 1206 & & & 1168 & \\
\hline 2001 & 1470 & & & 2340 & & 976 & \\
\hline 2002 & & & 1462 & 1910 & & 1201 & \\
\hline 2003 & & & 1428 & & & & \\
\hline 2004 & 1277 & & 1432 & 1669 & & 605 & \\
\hline 2005 & 1108 & & & 1368 & & 723 & \\
\hline 2006 & 757 & & 1169 & & & 758 & \\
\hline 2007 & 857 & & 868 & 1107 & & 585 & \\
\hline 2008 & 935 & 684 & & 1025 & 626 & 507 & 848 \\
\hline 2009 & & & & 853 & 498 & 689 & 769 \\
\hline 2010 & 1050 & & 954 & 1105 & & 502 & 899 \\
\hline
\end{tabular}

\section{Annual and monthly variation of wind power and energy density}

The annual and monthly mean WPD and wind energy density (WED) values calculated using Weibull parameters via Eqs. (7) and (8) are reported in Tables VI and VII and Figures $8(\mathrm{a})$ and $8(\mathrm{~b})$, respectively.

The WPD varied between $86.44 \mathrm{~W} / \mathrm{m}^{2}$ and $167.85 \mathrm{~W} / \mathrm{m}^{2}$, at $10 \mathrm{~m}$ above water surface level corresponding to years 2006 and 2001, respectively. The annual highest WPD of $267.15 \mathrm{~W} / \mathrm{m}^{2}$ was observed at Mykonos in 2001. Overall, no annual decreasing or increasing trends could be observed at any of the stations. An obvious seasonal trend with higher WPD values during winter time and lower in summer time was observed at all the stations except at Mykonos.

The annual mean values of WED are summarized in Table VII for all the stations. At Athos, WED values were found to be decreasing significantly from 2001 till 2006 and then increased slightly towards 2010. At Lesvos, the maximum WED of $1462 \mathrm{kWh} / \mathrm{m}^{2}$ was obtained in 2002 while a minimum of $868 \mathrm{kWh} / \mathrm{m}^{2}$ in 2007, as given in Table VII. At Mykonos the WED values varied between a minimum of $853 \mathrm{kWh} / \mathrm{m}^{2}$ and a maximum of $2340 \mathrm{kWh} / \mathrm{m}^{2}$ corresponding to years 2009 and 2001, respectively. At this site, a significant and continuous decrease in WED values was noticed right from 2001 till 2009. At Santotini buoys site, the maximum WED was found during year 2000 and a minimum of $502 \mathrm{kWh} / \mathrm{m}^{2}$ in 2010, as seen from Table VII. At this site also a decreasing trend was observed in the values of WED from 2000 till 2010, though slight. The seasonal trend of WED was almost the same as that of WPD, as can be seen from a comparison between the two parts of Figure 8 .

Well, it is true for all the locations, no matter offshore or onshore. Usually, for any wind farm installation, it is recommended to conduct wind measurements at the site of interest for one complete year and then estimate the uncertainty with historical data from nearby site. In the present work this has not been done, due to unavailability of site dependent data, but, as a rule of thumb, an uncertainty of $\pm 5 \%$ could be considered, while designing the actual wind farm.

\section{CONCLUSIONS}

The present study utilized 3 hourly measurements of wind speed and wind direction from 7 buoys stations in the Aegean Sea to assess the wind power potential using Weibull shape and scale parameters. Following are the main finding of the present work:

- The maximum wind speed of $7.45 \mathrm{~m} / \mathrm{s}$ at $10 \mathrm{~m}$ above water surface level was found at Mykonos and the minimum of $5.08 \mathrm{~m} / \mathrm{s}$ and $5.31 \mathrm{~m} / \mathrm{s}$ at Athos and Petrokaravo, respectively, while at all remaining locations the wind speed was more than $5.88 \mathrm{~m} / \mathrm{s}$. 
- The shape parameter values were around $1.5 \pm 0.25$ at all the locations. The scale parameter value was more than $5.89 \mathrm{~m} / \mathrm{s}$ for all the stations except at Athos where it was $4.78 \mathrm{~m} / \mathrm{s}$.

- At Mykonos, the most probable wind speed was found to be $4.97 \mathrm{~m} / \mathrm{s}$, while at Athos it was only 1.27. This simply means that Mykonos receives higher wind speed for most of the times while Athos the least.

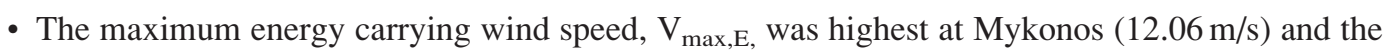
minimum at Petrokaravo $(9.22 \mathrm{~m} / \mathrm{s})$. This implies that a wind speed of $10.37 \mathrm{~m} / \mathrm{s}$ at Athos produced the maximum energy and so on.

- The mean wind speed was extrapolated to $90 \mathrm{~m}$ in steps of $20 \mathrm{~m}$ using the measured wind speed at 3 and $10 \mathrm{~m}$, the local wind shear exponent $\alpha=0.123$, and Eq. (1). The mean wind speed at Athos was $31 \%$ higher at $90 \mathrm{~m}(6.65 \mathrm{~m} / \mathrm{s})$ than that at $10 \mathrm{~m}(5.08 \mathrm{~m} / \mathrm{s})$. The increase in mean wind speed values was almost $31 \%$ in all the cases.

- The Weibull shape parameter values were almost the same at $10 \mathrm{~m}$ and $90 \mathrm{~m}$. The maximum value of $\mathrm{k}$ of 1.99 was at E1M3A station, while minimum at Athos. The scale parameter values at 10 and $90 \mathrm{~m}$ above water surface level followed almost similar trends as in case of mean wind speed.

- At Athos, a close agreement between the Weibull distribution function and the measured wind speed was obtained with $\mathrm{R}^{2}=0.90$. At E1M3A, Lesvos, Mykonos, Petrokaravo, Santorini, and Skyros the $\mathrm{R}^{2}$ values were $0.94,0.79,0.70,0.92,0.93$, and 0.94 , respectively. This exercise proved that the Weibull distribution can be used to represent the wind speed distribution with sufficient accuracy at these locations.

- At Athos, the wind speed was above cut-in-speed of $4 \mathrm{~m} / \mathrm{s}$ for $53.31 \%$ of the times during the data collection period and the predominantly blown from NS $(>45 \%)$. At E1M3A, the remained above cut-in-speed for more than $73.61 \%$ of the times and came from WN directions for $50 \%$ of the times. At Lesvos, Mykonos, and Petrokaravo, the wind remained above cut-inspeed for more than $67.5 \%, 78.68 \%$, and $61.01 \%$ of the times and was found to be blowing predominantly from NE, N-NS-NE, and NW, respectively. At remaining two stations the wind speed remained above cut-in-speed for more than $72.86 \%$ and $64.68 \%$ of the times. The wind direction was mostly found to be from N. Moreover, the percentage of times the wind speed was above cut-in-speed in all stations was found in proportion to the magnitude of the scale parameter value and the most probable wind speed as well and this linear relation was remarkably strong $\left(\mathrm{R}^{2}=0.832\right.$ and 0.897 , respectively).

\section{ACKNOWLEDGMENTS}

The authors wish to acknowledge the support of the Research Institute of King Fahd University of Petroleum and Minerals, Dhahran, Saudi Arabia and the Hellenic Centre for Marine ResearchPoseidon Team for the attainment of the access to the Centre's buoys database.

${ }^{1}$ S. A. Akdağ and Ö. Guler, Appl. Energy 87, 2574 (2010).

${ }^{2}$ H. Lund, Energy 32, 912 (2007).

${ }^{3}$ T. Ackermann and L. Söder, Renewable Sustainable Energy Rev. 6, 67 (2002).

${ }_{5}^{4}$ S. A. Akdağ and A. Dinler, Energy Convers. Manage. 50, 1761 (2009).

${ }^{5} \mathrm{H}$. Lund and B. Mathiesen, Energy 34, 524 (2009).

${ }^{6}$ Q. Y. Meng and R. W. Bentley, Energy 33, 1179 (2008).

${ }^{7}$ U. Bardi, Energy 34, 323 (2009).

${ }^{8}$ A. M. Papadopoulos, G. L. Glinou, and D. A. Papachristos, Renewable Energy 33, 105 (2008).

${ }^{9}$ A. N. Celik, Renewable Sustainable Energy Rev. 15, 2743 (2011).

${ }^{10}$ C. N. Maxoulis and S. A. Kalogirou, Renewable Energy 33, 355 (2008).

${ }^{11}$ Renewable Energy Focus: Booming wind power in Bulgaria, 11 November 2009 (http://www.renewableenergyfocus.com/ view/5174/booming-wind-power-in-bulgaria/).

${ }^{12}$ D. Lalic, K. Popovski, V. Gecevska, S. Popovska Vasilevska, and Z. Tesic, Renewable Sustainable Energy Rev. 15, 3187 (2011).

${ }^{13}$ G. Bekele and B. Palm, Appl. Energy 86, 388 (2009).

${ }^{14}$ D. A. Spera, Wind Turbine Technology, 3rd ed. (ASME, New York, 1995).

${ }^{15}$ J. F. Manwell, J. G. McGowan, and A. L. Rogers, Wind Energy Explained, 1st ed. (Wiley, England, 2002).

${ }^{16}$ P. Ramírez and J. A. Carta, Energy Convers. Manage. 46, 2419 (2005).

${ }^{17}$ M. Jamil, Wind Eng. 18, 227 (1994).

${ }^{18}$ J. P. Hennessey, J. Appl. Meteorol. 16, 119 (1977). 
${ }^{19}$ S. Rehman, T. O. Halawani, and T. Husain, Sol. Energy 53, 473 (1994).

${ }^{20}$ H. S. Bagiorgas, G. Mihalakakou, and D. Matthopoulos, Int. J. Green Energy 5, 120 (2008).

${ }^{21}$ H. S. Bagiorgas, M. N. Assimakopoulos, D. Theoharopoulos, D. Matthopoulos, and G. K. Mihalakakou, Energy Convers. Manage. 48, 1640 (2007).

${ }^{22}$ S. Rehman and N. M. Al-Abbadi, Energy Environ. 20-21, 1257 (2009).

${ }^{23}$ C. J. Baynes and A. G. Davenport, "Some statistical models for wind climate prediction," Preprints Fourth Conference Probability and Statistics in the Atmospheric Sciences, Tallahassee, FL (American Meteorological Society, Boston, MA, 1975), pp. 1-7.

${ }^{24}$ K. Jackson, C. P. van Dam, and D. Yen-Nakafuji, Wind Energy 8, 443 (2005).

${ }^{25}$ T. P. Chang, Appl. Energy 88, 1848 (2011).

${ }^{26}$ E. Kavak Akpinar and S. Akpinar, Energy Convers. Manage. 46, 515 (2005).

${ }^{27}$ A. Keyhani, M. Ghasemi-Varnamkhasti, M. Khanali, and R. Abbaszadeh, Energy 35, 188 (2010).

${ }^{28}$ N. Hamad, C. Millot, and I. Taupier-Letage, Scientia Marina 70, 457 (2006).

${ }^{29}$ S. E. Poulos, P. G. Drakopoulos, and M. B. Collins, J. Mar. Syst. 13, 225 (1997).

${ }^{30} \mathrm{~S}$. Incecik and F. Erdogmus, Renewable Energy 6, 863 (1995).

${ }^{31}$ Y. Borhan, Renewable Sustainable Energy Rev. 2, 353 (1998).

${ }^{32}$ Z. B. Klaić, Z. Pasarić, and M. Tudor, J. Marine Syst. 78, S101 (2009).

${ }^{33}$ D. Karamanis, C. Tsabaris, K. Stamoulis, and D. Georgopoulos, Renewable Energy 36, 815 (2011).

${ }^{34}$ S. A. Akdağ, H. S. Bagiorgas, and G. Mihalakakou, Appl. Energy 87, 2566 (2010).

${ }^{35} \mathrm{~W}$. Zhou, "Simulation and optimum design of hybrid solar-wind and solar-wind-diesel power generation systems," $\mathrm{Ph} . \mathrm{D}$. dissertation (Hong Kong Polytechnic University, 2008), pp. 218.

${ }^{36}$ T. V. Ramachandra, K. J. Rajeed, S. V. Krishna, and B. V. Shruthi, Energy Sci. Technol. 14, 61 (2005).

${ }^{37}$ A. S. S. Dorvlo, Energy Convers. Manage. 43, $2311(2002)$.

${ }^{38}$ M. Jamil, S. Parsa, and M. Majidi, Renewable Energy 6, 623 (1995).

${ }^{39}$ F. Pimenta, W. Kempton, and R. Garvine, Renewable Energy 33, 2375 (2008).

${ }^{40}$ Global Annual Installed Wind Capacity 1996-2010, Global Wind Statistics 2010, 2010, p. 3 (http://www.gwec.net/fileadmin/ documents/Publications/GWEC_PRstats_02-02-2011_final.pdf).

${ }^{41}$ Wind Power Share of Global Electricity Demand, Global Wind Energy Output 2010, 2011, p.10 (http://www.gwec.net/ fileadmin/documents/Publications/GWEO\%202010\%20final.pdf). 